UDC 621. 397.7: 621.377.6

\title{
放送局におけるディジタルテレビジョン 技術の動向
}

\author{
NHK 技術運用センター 谷村洋
}

最近，ディジタルメモリ一技術の進歩によって，テレビ信号のディジタル処理が実用化の段階に 入って来た．しかしディジタル化するに当っては，現在の技術では利点欠点があり，てれらをよく 検討したうえで取报っていかねばならない，実用化するに当っての問題をアナログ技術を基盤とし てどのように解決していかねばならないか，実用化されている機器，および今後開発されていく機 器について概要を説明し，今後の見通しについて解説した.

\section{1. まえがき}

こて数年来, ディジタル回路関係の部品の進歩は, め ざましいるのがある。これらの進歩に合せて，テレビ技 術に応用されているディジタル機器も順次開発され, 実 用化の傾向にある. したがって，てのディジタル化の波 は次第にテレビの分野におしよせて来ており，今後数年 間に，放送機器にも順次採用されていくであろう.

その理由としては, ディジタル回路の特長を生かした 方が，従来のアナログ回路にくらべて，保守運用の面か らおよび経済的面から考えて大いに利点があるからであ る.さらに技術的にみても，たとえば老朽化した機器を 新しいものに拉きかえる場合にも，ディジタル化した方 がスペースも狭くてすむし，コストも安いとすれば，誰 であ一応ディジタル化できないかと考えるであろう．し たがって，ここで現在の技術で考えたときテレビ関係の ディジタル化について解説する.

\section{2. ディジタル技術の利点と欠点}

テレビ技術も，放送開始以来アナログ回路ですべて組 み立てられているので，てれらを急にディジタル化する ことは，経済面からあ技術面からあかなりの困難をのり こえねばならない. したがってディジタル化するとして む, 現在のアナログ回路のテレビ放送システムのなか でディジタル化して，乙れをアナログ回路とおきえて も影響を与える範团の少ないものから順次変更されてい くことと思う。すでにディジタル化されたすのとしては

"Prospects for Digital Techniques in Television Broadcasting" by Hiroshi Tanimura (NHK Technical Operation Centre, Tokyo)
独立でその機能を充分に果せるあのが多い，たとえば， VTR 用のタイムベースコレクター, テレビ標準方式変 換装置，等がこれに相当する.

このようにディジタル技術を利用して，いままでのア ナログ技術を用いたものよりも優れた結果が得られるも のから順次ディジタル化されていく，乙れらは次に示す ような明らかな事実があるからである。すなわち，

（1）ディジタル技術はアナログ技術に比較して高度 な技術を駆使していて優れた結果が得られる。

（2）ディジタル化するてとによってコストを下げる ことができる可能性を大いにもっている.

（3）ディジタル回路の信頼性は，アナログ回路にく らべて大変優れている.

（3）したがって，故障発生は非常に少ないので，保 守，整備の手間がかなりはぶける。

等の理由からである.

特に, このうち(1)の理由は次に示すような性能をむ っているからである.

(1) SN 比はディジタル化した後の信号処理の度数に 無関係である。

(2) 出力レベルがディジタル回路システムの利得変化 に無関係である.

(3) 伝送路の非直線ひずみに影響されない.

(4) 信号をメモリーするのが容易にでき，メモリー時 間に関係なくその画質が変化しない。

(5) まったく新しいディジタル技術の導入によって, 日常の運用技術をみなおすととができる.

とのような利点を持っているが，一方では新しいあの は，必ず欠点ああるものである.すなわち 
(a) ある信号を伝送しようと思うと，アナログ信号の 場合よりあ, さらに広い伝送带域を心要々する.

(b) 装置の構成はディジタル化が進むにつれて複雑に なるので, 保守整備には, より高度の技術を必要と する.

\section{3. テレビ系を伝送も含めてディジタル化し た場合の全システムはどのようになるか}

現時点で，このシステムの予想を立てることはかなり むずかしいととであるが，すでにテレビにディジタル化 の技術が执しよせているので，いずれかの時点で, ディ ジタル化されたシステムが採用されるととになるである う.しかし，乙れああるとき一斉にディジタル化するの ではなく，技術的に，経済的に，メリットがあるという ことが明らかである部分から徐々にディジタル化されて いくであろう.

いずれにしてあテレビとは光学的イメージを電気信号 に変換し, 伝送路を通して長距離伝送し, 各家庭の受像 機で再び電気信号を光に変換して㯖視者に見せるあので あるから，入口と出口は必ずアナログ信号である. した がってディジタル伝送のためには, 必ずアナログから ディジタルへの変換, すなわち $\mathrm{A} / \mathrm{D}$ 変換器が必要とな る. さらに聴視者側にも D/A 変換器によって直接光信 号へまたはアナログ信号にしてからディスプレイへとい う手段が必要である.

一方，テレビ信号に限らず，ディジタル信号で情報を 伝送するのは，アナログ信号で伝送するより広い帯域が 必要となるので, できるだけその伝送帯域を狭くしてア ナログなみの帯域でディジタル伝送ができないものかを
検討しているが，てれはかなり困難な技術を含んでいる ので，その解答はまだ先になるのではなかろうか.

この問題の検討には, 放送業者のみで進めるのは片手 おちで, 放送にはネットワークが伴うため, その伝送を 担当する搬送業者屯含めて合同で検討を進めねばならな い. 現在のマイクロ回線の帯域はテレビ信号の伝送が主 体となって決められているが，令後ディジタル伝送によ る带域の決定はテレビのディジタル伝送を主体として決 められるよりも, むしろ音声の PCM 伝送の方が技術的 に進んでいるので，てれを主体に帯域の割当てが行われ る可能性が大きい. したがってテレビのディジタル伝送 の方式決定に当っては，乙れらの点む充分に考慮したう えで決めねばならないであろう。

現在, 電々公社で検討されているディジタル伝送の八 イアラーキは図1に示すようになっており，乙れに放送 用テレビ信号をディジタル化してはめ込むとすると適当 なものがなく, 何らかの処理をしてからこのハイアラー キのいずれかにはめ込まねばならない。したがって，わ れわれ放送業者が，伝送も考えてディジタル化するとき には, 局内のディジタル信号系もこの点を考えて, 伝送 路に渡せるようなビット構成で, 設計しておく必要があ る.

テレビのディジタル化はすでにかなり技術的に進めら れているので, いまのうちに伝送路も考えたディジタル 化の基準を決めるための検討を開始しなければならない 時期に来ている.

この他に，別の観点からディジタル化の標準化を考え ねばならないてとがある。それは，ディジタル技術はコ ンピューター技術の発展に負うとてろが大きい.したが

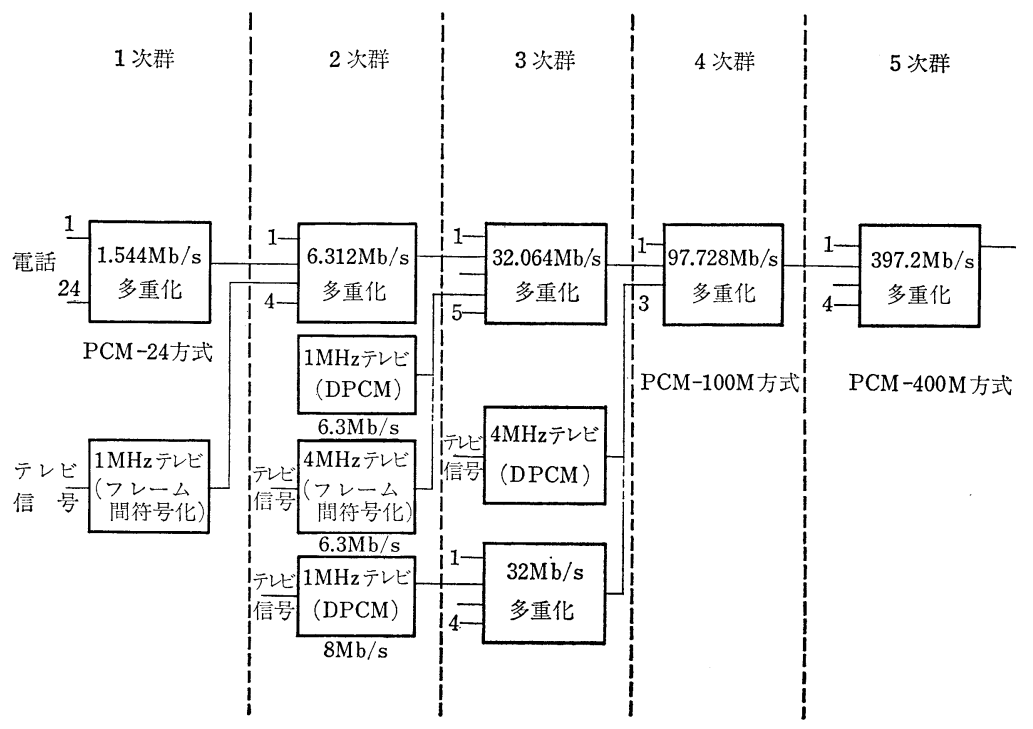

図 1 ディジタル伝送方式のハイアラーキとテレビ信号の多重化構成 
って今後のディジタルテレビシステムを組み立てていく ためにはコンピューターのハードウェアを有効に利用し て，乙れとの結合がスムースにいくようなディジタルテ レビの標準を決めていった方が，将来の抎張を含めて有 利に展開していくであろう.

\section{4. ディジタル化する場合に現在の NTSC 信} 号をどのような信号に分解してからディジ

\section{タル化すべきか}

この方法は大別すると，(1)NTSC 信号のままディジタ ル化する方法, (2) $Y, I, Q$ にデコードしてか,らディジタ ル化する方法, (3) $R, G, B$ にデコードしてからディジタ ル化する方法, の3つが考えられる.

こ机いつてあそれぞれ長所，欠点があるとと，およ び将来のディジタルテレビ系として伝送む考えたときに は，その標準化にも関連があるので，充分に検討しなけ ればならない問題である.

（1）まず，NTSC信号のままディジタル化する方法 について考えてみる.

これには，2つの方法がある. サンプリング周波数を $10.7 \mathrm{MHz}$ (カラーサブキャリヤ周波数の 3 倍）とする方 法と $14.3 \mathrm{MHz}$ （カラーサブキャリヤ周波数の 4 倍）と する方法である. システム系として考えたとき途中で復 調して Y,I, Q 亿する場合には $14.3 \mathrm{MHz}$ が好ましい. これは図 2 に示す例で考えると，PCM のサンプル制御 の位相を $+I,+Q,-I,-Q$ にすれば，
$\mathrm{A}$ と $\mathrm{A}^{\prime}=(1 / 2) I+Y$
$\mathrm{B}$ と $\mathrm{B}^{\prime}=(1 / 2) Q+Y$
C そ $\mathrm{C}^{\prime}=-(1 / 2) I+Y$
$\mathrm{D}$ と $\mathrm{D}^{\prime}=-(1 / 2) Q+Y$

となり， $I$ と $Q$ のデコードが大変易しくなる. しかし サンプリングの周波数が高いので, 回路素子の精度之性 能が $10.7 \mathrm{MHz}$ のサンプリングに比較してより高度の技 術が要求される。さらにメモリ一容量す多くなる。しか 七, カラーサブキャリヤは $3.58 \mathrm{MHz}$ であるから, 解像

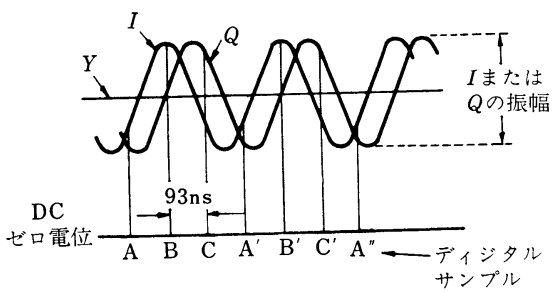

図 3 NTSC 信号の $Y, I, Q$ 成分を $10.7 \mathrm{MHz}$ で サンプルした場合

度および伝送等を考えたときの効率的運用としては $3 \times$ $f_{s c}$ の $10.7 \mathrm{MHz}$ のサンプリング周波数で充分である. しかし，乙のままで $Y, I, Q$ との関係をみると図 3 のよ うになり,

$$
\begin{aligned}
& \mathrm{A}=-(1 / 4) I-(\sqrt{3} / 4) Q+Y \\
& \mathrm{~B}=(1 / 2) I+Y \\
& \mathrm{C}=-(1 / 4) I+(\sqrt{3} / 4) Q+Y
\end{aligned}
$$

となり， $I$ と $Q$ のデコードをディジタル信号で行うに は， $4 \times f_{s c}$ よりは複雑になる.

このように，NTSC 信号をそのままで PCM 信号に エンコードする場合には $3 \times f_{s c}$ でサンプリングするか $4 \times f_{s c}$ でサンプリングするか，それぞれ長所短所があ るので，かなりむずかしい問題を含んでいる.

そてで, $3 \times f_{s c}$ でサンプリングしてあ, あとで信号 処理するときに便利なような方法を CBS Lab. で提案し ている.

これは PALE (Phase Alternating Line Encoding) 方式で, 櫛形フィルターをディジタル信号のまま作った り,デコードするときの容易さを考慮したあのである.

PALE のエンコード方式の系統を図 4 に示す. サンプ リング点のちがいを通常の $3 \times f_{s c}$ の場合と PALE し た方式の場合と比較したのを図 5 と図 6 亿示す.すなお ち PALE の場合はサンプリング点が垂直方向に並ぶの で，あとの処理が大変容易になる.

ディジタル信号処理は, 加算之減算に容易であるが, 乗算，除算は複雑になるので，できるだけ単純な信号処

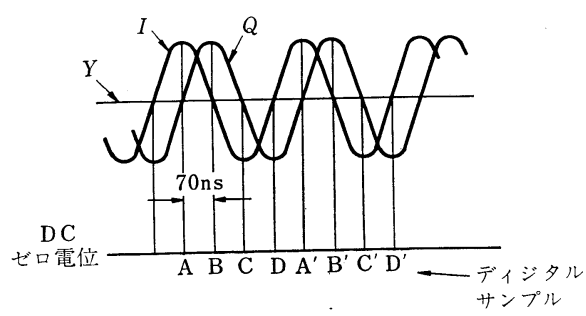

図 2 NTSC 信号の $Y, I, Q$ 成分を $14.3 \mathrm{MHZ}$ サンプルした場合

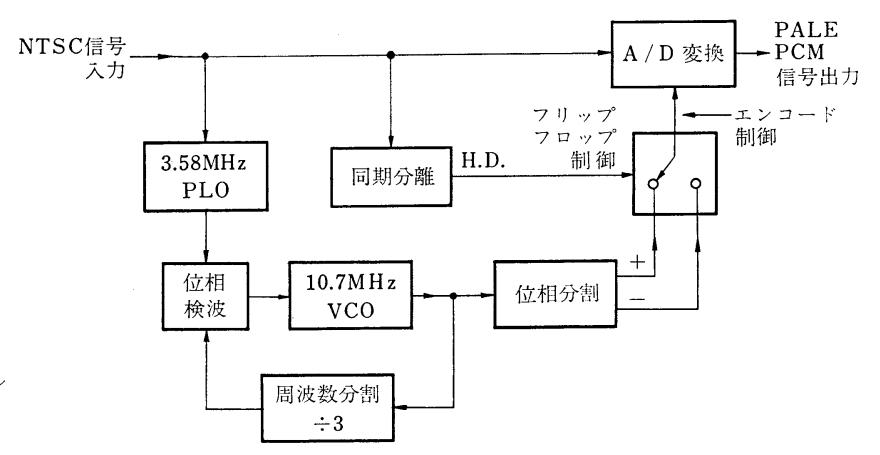

図 4 PALE エンコード方式 


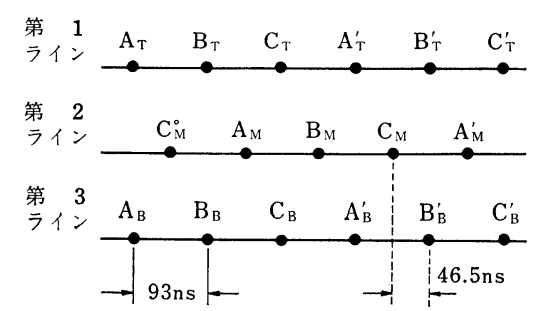

図 $510.7 \mathrm{MHz}$ でサンプルしたときの 3 ラインの関係

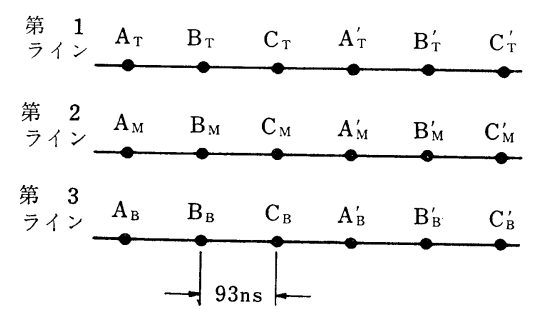

図 $6 \quad 10.7 \mathrm{MHz}$ の PALE 万式でサンプルしたと きの 3 ラインの関係

理でいけるようにして掠いた方が今後のディジタル技術 の発展のために望ましいととといえる。したがって，サ ンプリングは $4 \times f_{s c}$ が望ましいが，経済的な面から効 率を考えると PALE 方式が次に良い方法といえる.

(2) 次に $Y, I, Q$ にデコードしてからディジタル化 する方法についてみる．乙の方式はすでに実用化されて いて，後述するディジタル化したテレビ方式変換装置で 採用されている.

ての方法の利点は, 方式変換のように，NTSC から PAL へ変換するとき，たとえば NTSC 信号のままで ディジタル化すると, その後のライン数変換, 内插等の 演算が大変複雑になり，現実的には実現が非常にむずか しい．したがって，国際的な番組交換を考えて，伝送す るときには送信側で $Y, I, Q$ にディジタル化して，乙れ を多重化して伝送すれば，ディジタル方式変換装置を用 いて変換するのみで，エンコード，デコードの回数が減 り，伝送系として考えると，好ましい方法であるといえ る.

したがって，ディジタル方式変換も考えると $Y, I, Q$ で伝送するのが好ましい方式といえる，しかし，全体の 伝送帯域は $I, Q$ の帯域は狭いとしてあ $Y$ を含めて 3 チャンネル必要となるから, NTSC 信号を直接ディジタ ル化する方法よりは効率が悪いのは明らかである.

(3) 次に $R, G,{ }^{\prime} B$ 信号でディジタル化する方法す あるが，乙れはカメラの出力から直接ディジタル化でき るので，その面からみると大変便利であり画質も大変良 好であるが，その他の面からみて，利点になる所はあま りない，伝送路は信号の 3 チャンネル分必要となる．し かし $R, G, B$ 信号をディジタル化してから, 伝送のた
表 1 テレビジョンのディジタル化の方法の比較

\begin{tabular}{|c|c|c|c|c|c|}
\hline \multirow{2}{*}{ 信 号 } & \multirow{2}{*}{ コード化の方法 } & \multirow{2}{*}{$\begin{array}{l}\text { ビット率 } \\
\mathrm{Mbit} / \mathrm{sec}\end{array}$} & \multicolumn{3}{|c|}{ 忘 用 面 } \\
\hline & & & 制 作 & 記 録 & 伝 送 \\
\hline RGB & $\mathrm{PCM}$ & 250 & 0 & & 0 \\
\hline YIQ & $\mathrm{PCM}$ & 120 & 0 & & \\
\hline YIQ & DPCM & $45 \sim 50$ & & 0 & 0 \\
\hline NTSC & $\mathrm{PCM}$ & 90 & 0 & & \\
\hline NTSC & DPCM & $55 \sim 60$ & & 0 & 0 \\
\hline
\end{tabular}

めに多重する技術がディジタルで可能になるような良い 方法が考案されれば，关の時点で再検傠されるようにな るかも知れない。

光電変換の直後でディジタル化されるので，ディジタ ルテレビのトータルシステムとして考えるときには最む 単純にディスプレイ側で D/A 変換して原信号を再現す るととができる. この点については今後の撮像側の光電 変換素子と, 受信側のディスプレイ素子の開発にかかっ ている.NTSC方式以外の高精度テレビ方式への応用が 考えられる.

表 1 にディジタル化する場合の各方法について比較し てみた。

こてで，DPCM についてみてみると，ビット率がか なり下げられるので，伝送と記録のためには向いている が，やはり情報量を圧縮しているのでわずかな画質劣 化，たとえば急激な波形変化の部分でエッジビジネスの ような画質劣化があるので，完全な方法とはいえない． しかむDPCM はスタジオで用いるディジタル MIX は 不可能である.

\section{A/D コンバーター}

ディジタル化の入口とひいうべき $\mathrm{A} / \mathrm{D}$ コンバーター は，ディジタル信号の品質を決める重要なもののひとつ であり，また複雑でああるので，その特性をいかに良好 に保つかが最大の目標である. 一般にテレビ信号のディ ジタル化をする場合の 1 画素当りのビット数は 8 bit が 適当とされているが，世界各国での提案について表 2 亿 示す.

A/D コンバーターの種類は方式で分けるとかなり沢 山あるが，高速で，テレビ信号用として使えるものは， 大きく分けると 4 つ位である.

すなわち，帰還型，緃続型，ての 2 つを組合せた直並 列型，並列比較型である。乙れらはそれぞれ長所，短所 があり, 絟続型は 1 ビットずつカスケードに接続してい くので, ビット数が増えると各段の増幅度の安定度によ って誤差を生ずるので，精度の良いものはむずかしい． 帰還型は上位ビットから順次ディジタル化するので, D/A コンバータによって州還しながら順次下位ビット 
妾 2 ディジタル化の提案

\begin{tabular}{|c|c|c|c|c|c|c|c|c|}
\hline 提案機関 & テレビ信号 & $\begin{array}{l}\text { 带 域 幅 } \\
(\mathrm{MHz})\end{array}$ & $\begin{array}{c}\text { サンプル周波数 } \\
(\mathrm{MHz})\end{array}$ & $\begin{array}{l}\text { サンプル当り } \\
\text { ビット数 }\end{array}$ & コード化の & 量子化雑音 & $\begin{array}{l}\text { 全ビット率 } \\
\text { (Mbit/s) }\end{array}$ & $\begin{array}{l}\text { 許容ビットエ } \\
\text { ラー率 }\end{array}$ \\
\hline $\mathrm{BBC}$ & PAL $625 / 50$ & $0 \sim 5.5$ & 13.3 & 9 & 直線 PCM & $\begin{array}{c}52 \mathrm{~dB} \\
\text { 評価 } S / N\end{array}$ & 119.7 & $10^{-A}$ \\
\hline ITT & PAL $625 / 50$ & $0 \sim 5.5$ & 13.3 & 8または 9 & 直線 PCM & $\begin{array}{c}52 \mathrm{~dB} \\
\text { 評価 } S / N\end{array}$ & $\begin{array}{c}106.4 \\
\text { 又は } 119.7\end{array}$ & $\begin{array}{c}10^{-8} \\
\text { 総合で } 10^{-9}\end{array}$ \\
\hline ATT & NTSC $525 / 60$ & $0 \sim 4.5$ & 10.290 & 9 & 直線 PCM & - & 92.610 & $10^{-6}$ \\
\hline 西ドイッ & PAL $625 / 50$ & $0 \sim 5$ & 7. 61 & 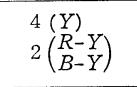 & DPCM & - & 34.270 & 研究中 \\
\hline COMSAT & NTSC $525 / 60$ & $0 \sim 4.5$ & $\begin{array}{l}Y / 6.02 \\
I / 1.77 \\
Q / 0.686\end{array}$ & $\begin{array}{l}Y / 5 \\
I / 4 \\
Q / 4\end{array}$ & $\begin{array}{l}\text { 双方向 } \\
\text { DPCM }\end{array}$ & - & $\begin{array}{c}\quad 33.4 \\
\text { エラ一補正に } \\
4.2 \text { 用いる }\end{array}$ & 研究中 \\
\hline $\mathrm{BBC}$ & PAL 625/60 & $0 \sim 5.5$ & 13.3 & 7 & $\mathrm{DPCM}$ & $\longrightarrow$ & 77 & 研究中 \\
\hline
\end{tabular}

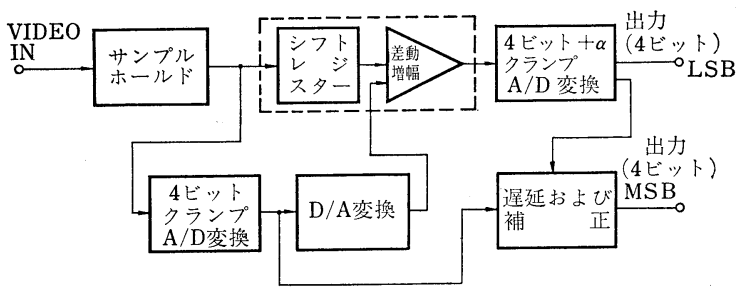

図 7 NHK の A/D コンバーター

を作っていく．したがって精度は良いものが作れるが， テレビ用としては高速性が要求される.

直並列型は上の 2 つ利点をうまく組合せたもので， NHK および BBC でそれぞれ独立に考案した. これが 将来のテレビ用 $\mathrm{A} / \mathrm{D}$ コンバーターとしては最む望みが 大きい.

$\mathrm{NHK}$ の A/D コンバーターの系統図を図 7 に示す. この主な特長は, サンプル周波数は $11 \mathrm{MHz}$ 以上, 1 ワ ード当り $8 \mathrm{bit}, 0^{\circ} \mathrm{C} \sim 50^{\circ} \mathrm{C}$ で安定に動作する. 小型で安 価に製作できる. 入力信号レベルは $1.0 \mathrm{~V} \mathrm{p}-\mathrm{p}$ で, 精度 が大変良い。

$\mathrm{BBC}$ の $\mathrm{A} / \mathrm{D}$ コンバーターの系統図を図 8 に示す. NHK の方式と非常によく似ている. 8 bit で $15 \mathrm{MHz}$ ま での周波数をディジタル化することができ, NTSC, PAL 信号に対して DG，DP はもちろんのこと，直線性も大 変良好である。

\section{6. ディジタル VTR}

現在のテレビ用 VTR は，改良に改良を重ねて受像機 でみる限りでは，生放送とほとんぞ分別がつけにくい程 度にまで，その品質は向上している．しかし，単体機器 としてまとまっているので，ディジタル化することむ割 合容易にできる機器のひとつである.すでに英国 BBC では，実験的に試作機を製造した．図 9 亿実験機の系統 図を示す.

記録容量としては約 $80 \mathrm{Mb} / \mathrm{sec}$ から $100 \mathrm{Mb} / \mathrm{sec}$ 程度 とかなりの量を必要とするので, 現在の磁気記録技術で は, アナログ記録に比較して記録媒体が多量に必要であ る. 符号化の方法，また記録のために特殊な変調方式を 用いるなどして，できるだけ記録容量を減らすととを考 える必要がある，また，将来のディジタル伝送を考える と，その符号化基準についても互換性考考慮して扔いた 方が良い。

いずれにしてあVTR は今後のテレビのディジタル化 について重要なポイントのひとつであるので, 充分に検 討して今後 5〜10 年間に実用化にあっていくことを考え ていかねばならない。

タイムベースコレクターがすでにディジタル化されて いるととあ考えると，ディジタル VTR が実用化される と, サーボ系を含めて, メカ系はジッターに対しての規

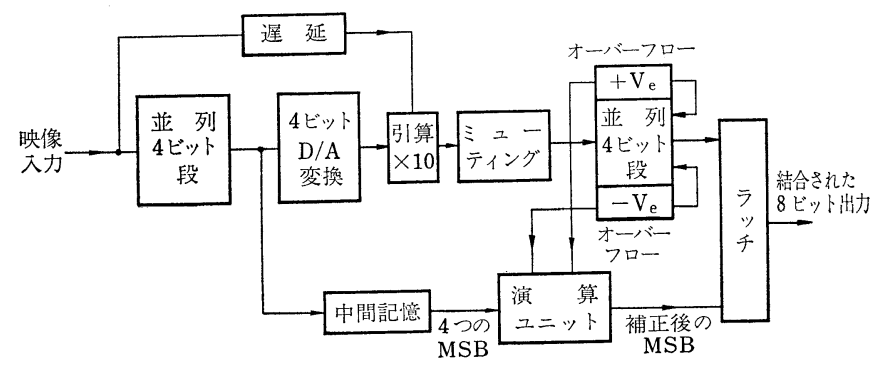

図 $8 \mathrm{BBC}$ の $\mathrm{A} / \mathrm{D}$ コンバーター 


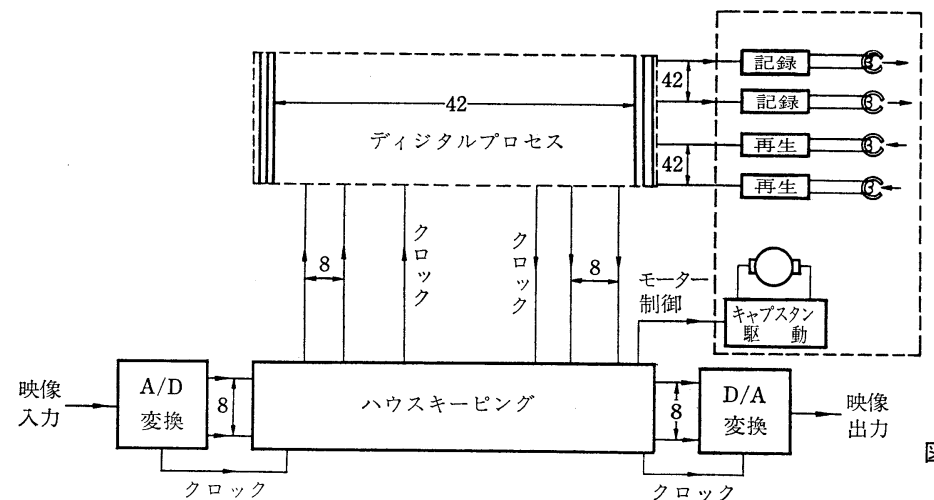

図 $9 \mathrm{BBC}$ におけるディジタル VTR の実験 系統図
格はかなりゆるめるととができる、したがって、コスト あ安くなるであろう。ささらにVTR は編集が行われ，そ のたびにコピーを重㸚るので画質が次第に劣化していく が, ディジタル化すればての問題は解決し, 編集が複雑 になってあ美しい画面が得られるであるう.

しかし， あとで述べる信号の混合等のスタジオ作業的 なものが，容易にディジタル技術を駆使してできるよう にならないとアナログ信号とディジタル信号が局内に混 在するので, 運用は複雑になる。

図 10 亿英国 IBA で発表したバイナリコード化して記 録するひとつの手法について説明する.

入力データ ( a ) とレベル基準信号 ( b ) とを比較し, 両

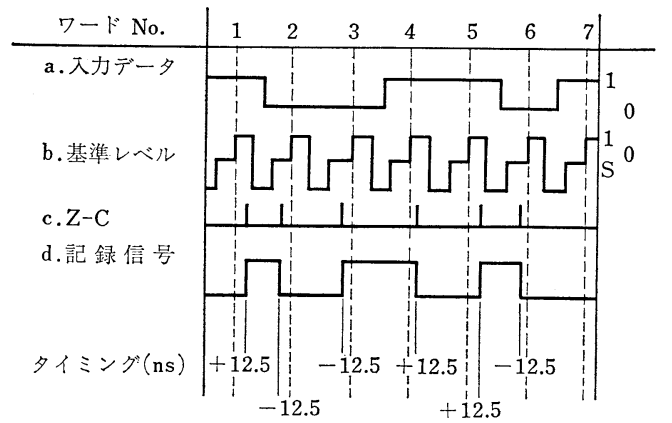

(a) 入力処理 (バイナリー)

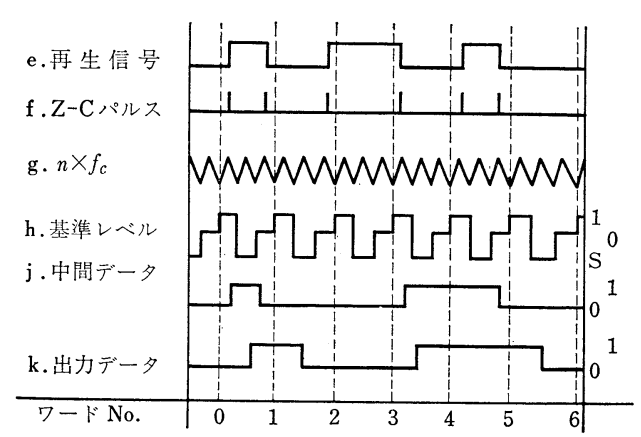

(b) 出力処理 (バイナリー)

図 10 バイナリーコードによるディジタル VTR の方法

$614(16)$
信号のレベルが一致した時 ( c ) のような Z-C (ゼロクロ スパルス）を発生する．とのパルスで記録電流の符号が 反転する(d).テープの再生信号 (e) は微分して両波整 流し，Z-C(ゼロクロス) パルス(f)を作る.

(f) で共振回路を励振して入力クロックパルスの整数 倍のパルス $(\mathrm{g})$ を作り，乙れから再生側のレベル基準信 号 ( h h )が作れる. 次に ( f ) とレベル基準信号 $(\mathrm{h})$ の一致 をみて, 中間データ $(j)$ が得られる. 最後に $(j)$ をレベ ル基準信号 $(\mathrm{h})$ の負のエッジの直後でサンプルすれば, 出力データ $(k)$ が得られる. (k) と ( a ) は同一のあので ある。

サンプリングの各ワード間隔は約 $75 \mathrm{~ns}(1 / 13.3 \mathrm{MHz})$ となる. 記録信号の Z-C 点は, 眓の点線に対して, 土 $12.5 \mathrm{~ns}$ の位相差をむつため, タイミングエラーは 12.5 ns 以内になければならない，Z-C 点ドリフトは再生時 のレベル基準信号により補正されるので, 問題となるの はスピードの早いドリフトである，実際には，このドリ フトは, $0.5 \mathrm{~ns} \mathrm{p}-\mathrm{p}$ であり, 許容誤差 $12.5 \mathrm{~ns}$ に対して $25: 1$ の安全率がある.

\section{7. スタジオ機器}

カメラからの出力信号のディジタル化については先に 述べたように，どのような形式の信号でディジタル化す るかによってかなり変化があるが，いずれにしてあ，ス タジオ副調に拉いて，MIX，ワイプ等をすべてディジタ ル信号で処理することが必要である。最す容易な方法は NTSC 信号をディジタル化してから処理するのが良い が，ガンマ補正，カラーマスキング等は RGB 信号の方 が容易である.

カメラの出力に付加している, イメージェンハンサー のディジタル化は，すでに CBS Lab. で実験が完了して いるが，これは NTSC 信号にェンコードしたのちに， ディジタル化してからイメージエンハンサーをディジタ ル技術で完成させた．しかし，すべてディジタル化する 


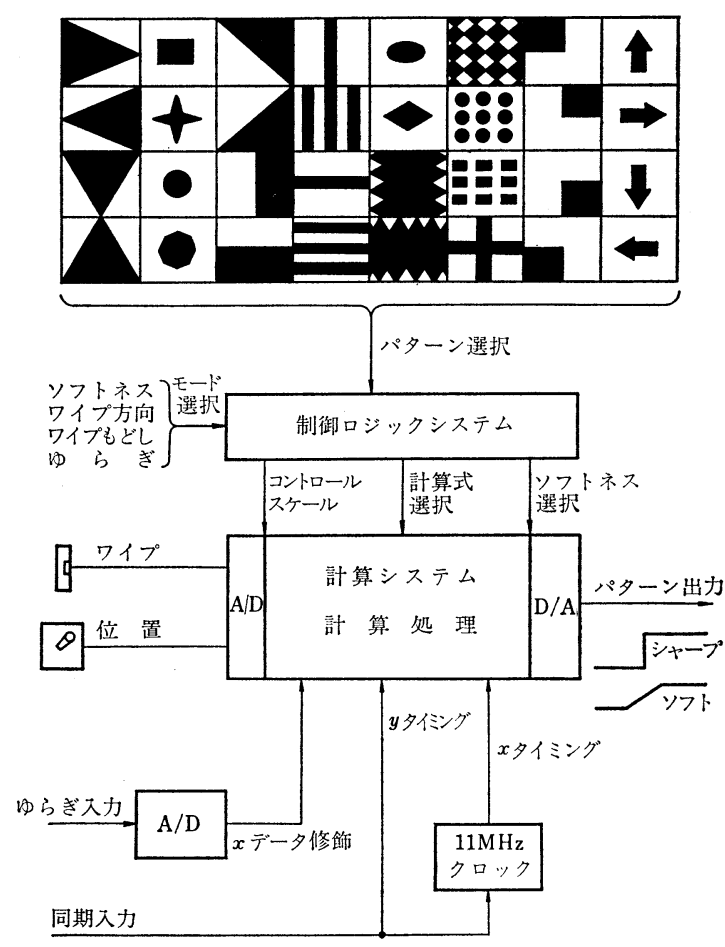

図 11 モンタージュパターン発生器の系統図

のはまだ経済的に有利ではないので，一部はアナログ信 号のままである. また，ピークホワイトのリミッターと か, 黑レベルクリッパーあ NTSC 信号をディジタル化 してから処理した方が有利である.

ディジタルミクサーも容易にできるが，並列型ディジ タル信号か, 直列型ディジタル信号かによって, その回 路は異なる. 特殊効果のワイプやモンタージュあディジ タル信号で処理することができる.

図 11 にモンタージュパターン発生器の一例を示 す. また局外中継とのワイプや混合む後述するフレ ームシンクロナイザーがすでにディジタル化されて いるので，乙れを用いればスタジオのカメラ出力す ディジタル化することによって，スタジオ内のスイ

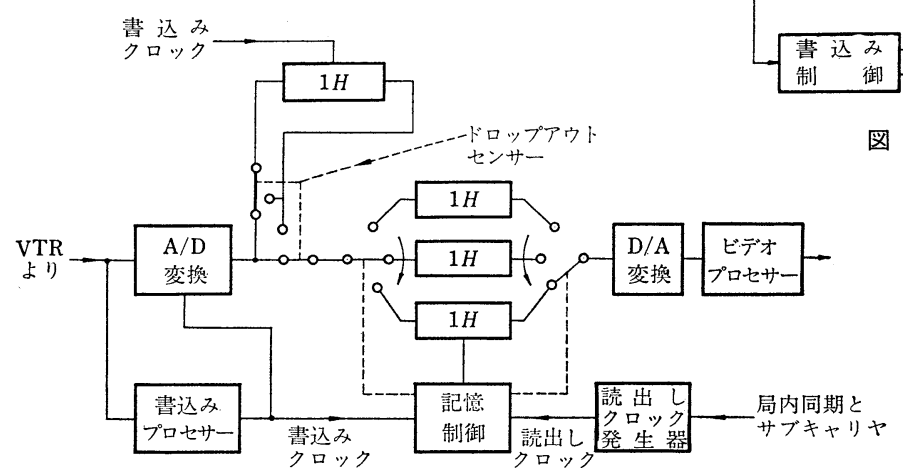

図 12 ディジタルタイムベースコレクター

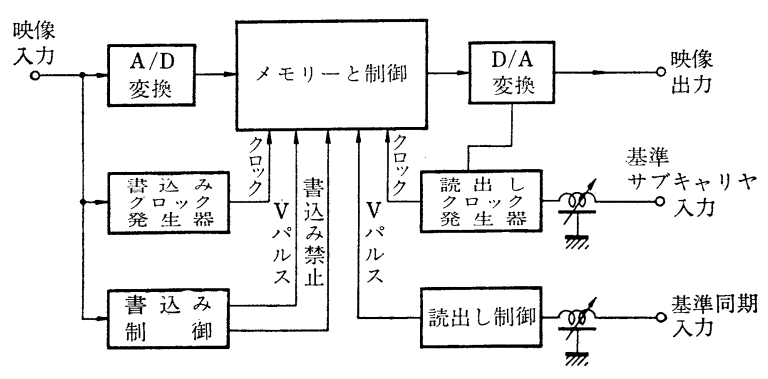

図 13 フレームシンクロナイザー
ッチングをすべてディジタル処理することができる.

しかし，これらあ現在はまだ経済的にみてアナログ信 号で扱った方が有利であるので，明日にあディジタル化 するのではなく，他の部門のディジタル化の進歩と調和 をはかりながら進めていくべきである.

\section{VTR 用タイムベースコレクター}

VTR の再生信号に含まれるジッターを補正し，スタ ジオの画と同一の同期で再生することは運用のうえで大 変便利である. 図 12 に系統図の一例を示す. 特にへリ カル走査型 VTR は，このタイムベースコレクターを 入れることによって放送用の規格にすることができるの で，安価なVTR が放送用に使えるので，有益な手段 である.

表 3 に，各社のタイムベースコレクターを示す．対象 VTR にはへリカル走查型のみに適用できるあのと，画 面内でスイッチングする $4 \mathrm{H}$ 型にあ利用できるものとが ある・

\section{9. フレームシンクロナイザー}

テレビ信号の中継放送の場合，入って来る信号が $1 つ$ の場合は，乙れにゲンロックをかけてスタジオ信号と混 合，ワイプができるが，2つ以上の場合にはそのつどゲ ンロックしなければならない，乙れらの不便さを解決す るために考案されたのがフレームシンクロナイザーであ る.これもディジタル技術を応用したもので, 外部から 入った信号をフレームメモリーに書込み，自局の同期信 号で読出しを行えば，その出力信号は自局とまったく位 相関係が一致する．したがってゲンロックまたは従来用 いられていたルビジゥム多元同期方式でトラブルの発生 
表 2 各社ディジタルタイムベースコレクターの比較

\begin{tabular}{|c|c|c|c|c|c|}
\hline 型 & 補正範囲 & 残留ジッター & 補 正方式 & $S / N$ (pprms) & その 他 \\
\hline CVS-500 & $\begin{array}{c} \pm 63.5 \mu \mathrm{s} \text { 以上 } \\
( \pm 1 H)_{i}\end{array}$ & $\pm 4 \mathrm{~ns}$ & $\begin{array}{c}\text { ディジタルシフトレジスター } \\
\text { MOS-3H } \\
8 \text { bit PCM } \\
10.7 \mathrm{MHz}\end{array}$ & $55 \mathrm{~dB}$ & ヘリカル VTR 用 \\
\hline CVS-504A & $\begin{array}{c} \pm 63.5 \mu \mathrm{s} \text { 以上 } \\
( \pm 1 H)\end{array}$ & $\pm 4 \mathrm{~ns}$ & 同上 & $50 \mathrm{~dB}$ & ヘリカルVTR 用 \\
\hline TMI-600 & $\begin{array}{c} \pm 90 \mu \mathrm{s} \\
( \pm 3 / 2 H)\end{array}$ & $\begin{array}{c} \pm 2 \mathrm{~ns} \\
\text { カラー } \\
\pm 3^{\circ}\end{array}$ & 9 bit & $60 \mathrm{~dB}$ & $\mathrm{CFC}$ 付 \\
\hline $3 \mathrm{M}$ & $\pm 80 \mu \mathrm{s}$ & カラー $2^{\circ} \mathrm{p}-\mathrm{p}$ & $\therefore$ bit PCM & $56 \mathrm{~dB}$ & $\mathrm{CFC}, \mathrm{DOC}$ は外付 \\
\hline CBS (CLD-1500) & $\begin{array}{l}190 \mu \mathrm{sp}-\mathrm{p} \\
( \pm 1.5 \mathrm{H})\end{array}$ & $\pm 4 \mathrm{~ns}$ & $\begin{array}{c}\text { RAM } 3 H \times モ リ ー \\
\text { 8bit PCM }\end{array}$ & $55 \mathrm{~dB}$ & $\begin{array}{c}\mathrm{DOC} \text { 付 } \\
\text { ヘリカルVTR 用 }\end{array}$ \\
\hline $\begin{array}{l}\text { QUANTEL-IVC } \\
\text { (TBC-2000) }\end{array}$ & $\begin{array}{l}190 \mu \mathrm{s} p-\mathrm{p} \\
( \pm 1.5 \mathrm{H})\end{array}$ & $\pm 4 \mathrm{~ns}$ & $\begin{array}{c}10.7 \mathrm{MHz} \\
8 \mathrm{bit} 4 H \text { ×モリー }\end{array}$ & $60 \mathrm{~dB}$ & $\begin{array}{l}\text { ヘリカルVTR 用 } \\
\text { CFC, DOC 付 }\end{array}$ \\
\hline $\operatorname{AMPEX}(\mathrm{TBC}-800)$ & $\begin{array}{r} \pm 63.5 \mu \mathrm{s} \\
( \pm 1 H)\end{array}$ & $\begin{array}{l}\text { モ゙ } \pm 10 \mathrm{~ns} \\
\text { カラー } 22.5 \mathrm{~ns}\end{array}$ & & $60 \mathrm{~dB}$ & $\begin{array}{c}\text { ヘリカルVTR 用 } \\
\text { DOC. }\end{array}$ \\
\hline NEC (H-1572) & $\begin{array}{l}63.5 \mu \mathrm{sp}-\mathrm{p} \\
( \pm 0.5 H)\end{array}$ & カラー $1.5^{\circ} \mathrm{p}-\mathrm{p}$ & $\begin{array}{l}8 \text { bit } \mathrm{PCM} \\
10.7 \mathrm{MHz}\end{array}$ & $50 \mathrm{~dB}$ & ヘリカル VTR 用 \\
\hline
\end{tabular}

(注) CFC (Color Fluctuation Control) 色むら補正器, DOC (Drop out Compensator) ドロップアウト補正器

原因であったループ制御から解放されるのでシステムが

簡易化される.

この装置はさらにVTR システムにあ利用できる。す なわち，VTR の再生モードは H-ロックモードでこの フレームシンクロナイザーを通してスタジオにインサー トできる. またタイムベースコレクターの機能も含ませ れば，VTR の再生モードはノルマルモードであよく なり，系統上，運用上単純になる，国産では，NEC の
FS-12 形がある. この性能は 2 フィールドメモリーで, 8 bit PCM でクロックは $10.7 \mathrm{MHz}$ である. メモリー は MOS RAM を用いている. 系統図を図 13 に示す.

\section{0. 方式変換装置}

方式変換の一番初期は，いわゆる再撮像といわれた光 電変換であった. てれは八レーション, ビームスポット の大きさ, ボケ, ブラウン管の粒状性のキズ, 解像度,
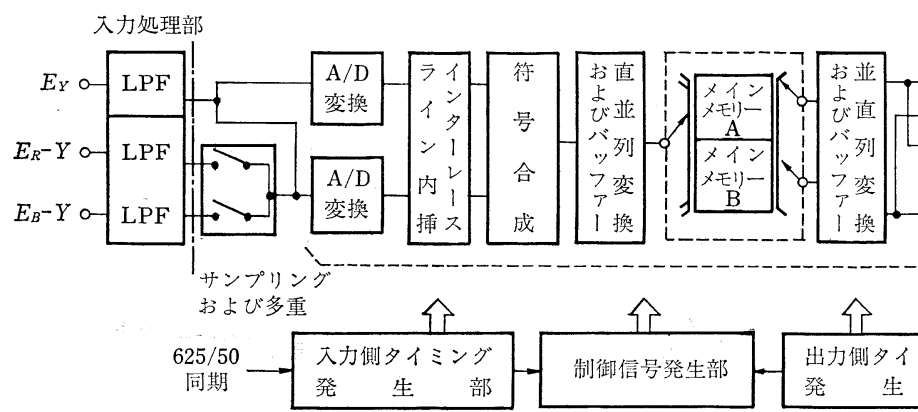

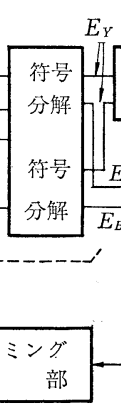

$E_{Y}$<smiles>[3H]CC[3H]</smiles>

$E_{Y}$ 出力処理部
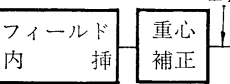
変換 LPF $\multimap E_{Y}$

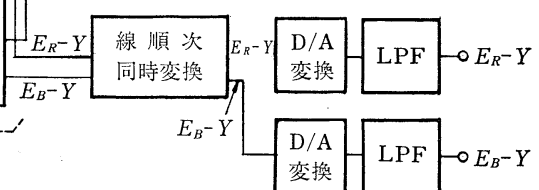
$525 / 60$

(a) 正変換 $(625 / 50 \rightarrow 525 / 60)$
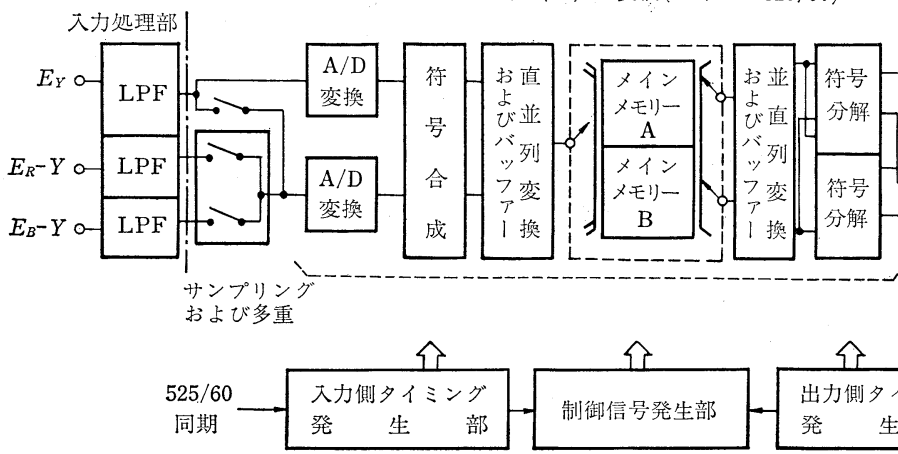

$E_{Y}$ 同期
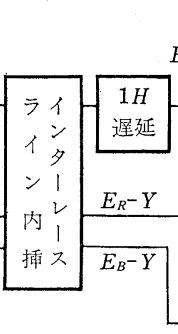

$E_{Y}$

出力処理部一

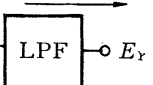

変換 LPF

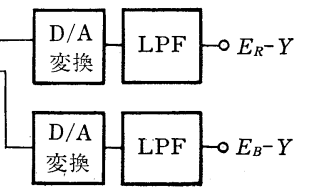

(b) 逆変換 $(525 / 60 \rightarrow 625 / 50)$

図 14 NHK ディジタル方式変換装置 


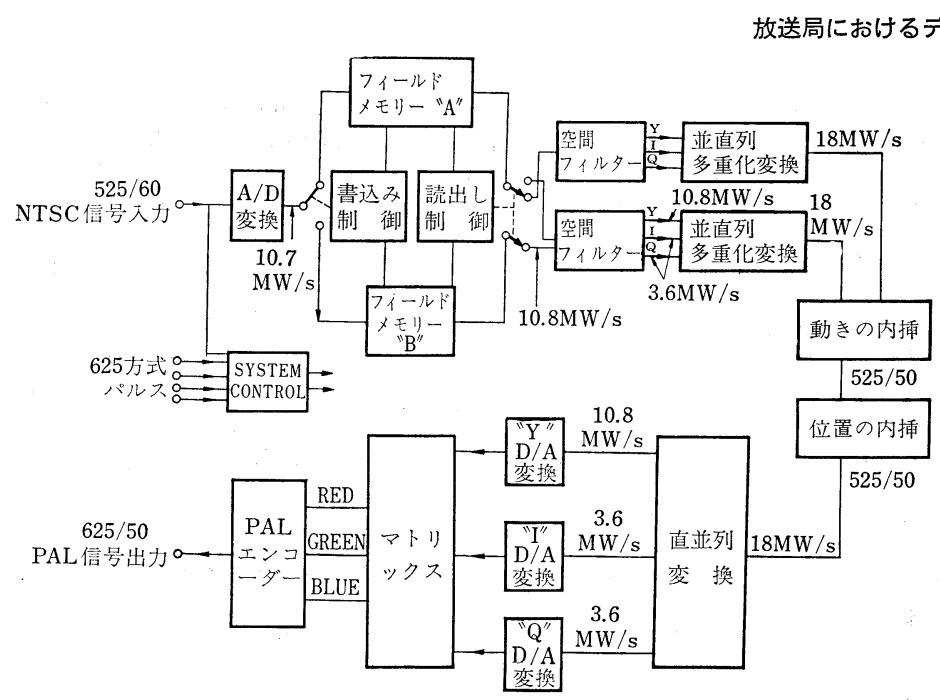

図 15 IBA ディジタル方式変換装置

バーニング等の問題点がある.さらにての改善のために 全電子式のアナログ型方式変換があったが，乙れは遅延 線を用いているためコストが高く，装置も大きくなる．

テレビ信号をディジタル化すると，変換プロセスはや や複雑になるが，アナログ信号の変換で面倒な温度特性 の影響, 增幅器の利得変化, 群遅延ひずみの補正等が不 要になるので，かなり改善される. ディジタル信号に変 換したあとのライン内挿，フィールド内插はすべて数学 的計算の精度に支配されるので，画質は設計したとおり になる。

NHK のディジタル方式変換系統図を図 14 に示し, 英国 IBA のディジタル方式変換の系統図を図 15 に示 す.

画質はアナログ型に比較して大いに改善された. 今後 検討すべき問題は，内插をさらに複雑にして動きの不自 然さをなくすことにある.
11. テレビ付帯音声信号など

音声をディジタル化してテレビ信号と同時伝送する方 法は，ユーロビジョンネットワークですでに実用化され ている.とれは SIS 方式 (Sound In Sync) (図 16) と いい，水平ブランキング期間に $14 \mathrm{kHz}$ 帯域の信号を 10 bit で伝送するあのである. また, 音声信号のみのデ ィジタル化と録音技術はレコード会社での円盤レコード (LP レコード) の原盤をカットするときのマスター信 号源や標準信号源としてすでに数社で製品が完成してい る.しかしまだ放送局で実用化するまでには至っていな い.とれには $6 \mathrm{~mm}$ テープのように容易に編集できない 等の, 未解決の問題が残っている.

12.むす び

放送へのディジタル技術の応用については，まだその 緒についたばかりであり，システム的にどうするかは今

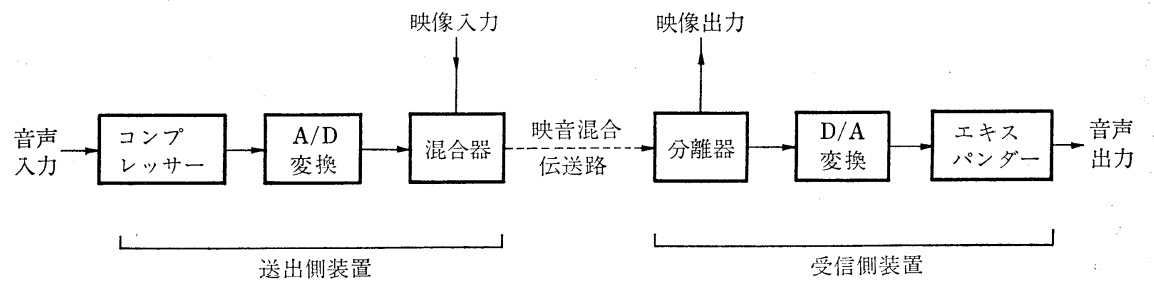

(a) 系統困

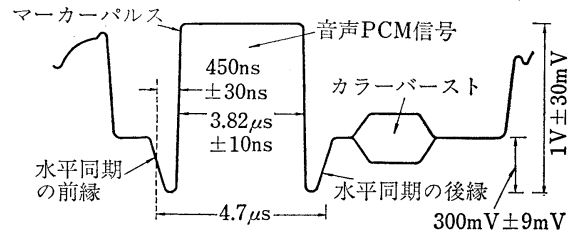

（b）水平ブランキング期間の波形

図 16 ユーロビジョン SIS の方式 
後の技術の発展と，標準を決めるための国際会議の結果 にかかっている.

さし当っては，ディジタル化できる機器から徐々に開 発していくことになる．特殊な装置，たとえば方式変換 装置, VTR 用のタイムベースコレクター, フレームシ ンクロナイザー等はすでに害用化されている. 令後はイ メージェンハンサー, 特殊効果装置等への利用が考えら れ，次第にビデオプロセスの部門へ拡大していくであろ う.

ディジタル化はスタジオ設備, VTR, カメラ, テレ シネ等の老朽化に伴って新機種導入の時期に，アナログ 方式で導入するよりも，システム的にも，また経済的に あ有利と判断したときに実施されていくであろう.

放送には，ネットワークが必要であるので，回線網を ディジタル信号で伝送するととが必要となり，電々公社 の電話用のハイアラーキとの関係が重要なポイントとな る.

(昭和 50 年 4 月 11 日受付)

\section{〔参考文 献〕}

1）林 宏三：なぜディジタル化が必要か，放送技術，9 (1974)

2) A. V. Lord: Digital Methods Applied to Television, The Royal Television Society Journal, 12, 2 (1968)

3) A. A. Goldberg: PCM Encoded NTSC Color Television Subjective Test, J. SMPTE, 82, 8 (1973)

4) F. G. Parker: Why Digital? Part 1 -Some Pros and Cons, The Royal Television Society Journal, May/ June (1973)

5) W. G. Simpson: Why Digital? Part 2--Distribution Links and Telecommunications, The Royal Television Society Journal, July/Aug. (1973)

6) J. L.E. Baldwin: Why Digital? Part 3-The Digital Television Studio Centre, The Royal Television Society Journal, Sept./Oct. (1973)

7) Pat Hawker: An Introduction to Integrated Circuits and Digital Electronics, IBA Technical Rev., June (1973)

8) 谷村 洋: ディジタル技術のビデオへの応用，テレビ学 会方式回路研資（昭 49.8）

9) J.P. Rossi: Color Decoding a PCM NTSC Television Signal, J. SMPTE, 83, 6 (1973)

10) Use of Digital Techniques in Broadcasting, EBU Tech. 3208-E, June (1974)

11）樋下重彦：画像信号の DPCM 符号化, テレビ誌, 28, 12 (1974)

12）石田順一：ディジタルテレビジョン，N N K 技研月報, 16, 5 (1973)
13) V.G. Devereux, et al. : Bit Rate Reduction of Digital Video Signals Using Differential PCM Techniques, IBC 1974 Conference Publication, 83-89

14) R. E. Fletcher: A Video Analogue to Digital Converter, IBC 1974 Conference Publication, 47-57

15) A.H. Jones, et al. : An Experimental Approach to Digital Television Recording, IBC 1974 Conference Publication, 114-118

16) J.L.E. Baldwin: The Digital Future of Television Studio Centres, IBA Technical Rev., June (1973)

17) J.P. Chambers: The use of Digital Techniques in Television Waveform Generation, IBC 1974 Conference Publication, 90-96

18) R.W. Fenton, et al.: Special Effects Employing Digital Pattern Generation, IBC 1974 Conference Publication, 14-20

19) J.P. Rossi: Digital Television Image Enchlancement, SMPTE 116 th Technical Conference No. 3

20) D. J.M. Kitson, et al. : Digital Time Base Correction, IBC 1974 Conference Publication, 119-126

21) 加納顕一ほか: Television Frame Synchronizer, SMPTE 116 th Technical Conference No. 7

22) R. J. Butler : Operational Implementation of a Frame Synchronizer, SMPTE 116 th Technical Conference No. 8

23) 谷村 洋, 後藤嘉治雄, 東 信義, 奥寺俊彦: ディジタ ル化したテレビジョン標準方式変換装置, NHK 技研月 報, 17，4 (1974)

24）林 宏三：ディジタルテレビと方式変換, NHK技研月 報, 16, 3 (1973)

25) J. L.E. Baldwin, et al. : A Standards Converter using Digital Techniques, Royal Television Society Journal, 14, 1, 3-11

26) J.L.E. Baldwin : New Techniquesin Television Standards Conversion, IBC 1970 Conference Publication, No. 69, 198-200

27) 吉田純一ほか: Digital Field Store Television Standards Converter, IBC 1974 Conference Publication, 104-113

28) J.L.E. Baldwin, et al.: A Standards Converter Using Digital Techniques, IBA Technical Rev., June (1973)

29) BBC Sound-in-Sync System, BBC Engineering Design Information.

30) M.G. Croll, et al. : Digital Sound Signals? the Present BBC Distribution System and a Proposal for bit-rate reduction by Digital Companding, IBC 1974 Conference Publication, 90-96

31) M. Hausdörfer: Contribution to the Digital Transmission of Colour TV Signals, IBC 1974 Conference Publication, 274-278

32) F.H. Wise: The Application of Digital Techniques to Radio Frequency Circuits, IBA Technical Rev., June (1972) 